\title{
Helicobacter mustelae
}

National Cancer Institute

\section{Source}

National Cancer Institute. Helicobacter mustelae. NCI Thesaurus. Code C86439.

A species of microaerophilic, Gram negative, helical/vibroid shaped bacteria assigned to the phylum Proteobacteria. This species is motile by multiple flagella and is considered an animal model of Helicobacter infection in humans. H. mustelae is part of the normal flora of the ferret gastrointestinal tract and causes peptic ulcer disease and chronic atrophic gastritis. 